\title{
MODERN MANAGEMENT: \\ GOOD FOR THE ENVIRONMENT OR JUST HOT AIR?
}

\author{
Nicholas Bloom \\ Christos Genakos \\ Ralf Martin \\ Raffaella Sadun \\ Working Paper 14394 \\ http://www.nber.org/papers/w14394 \\ NATIONAL BUREAU OF ECONOMIC RESEARCH \\ 1050 Massachusetts Avenue \\ Cambridge, MA 02138 \\ October 2008
}

We would like to thank the Anglo-German Foundation, the Economic and Social Research Council and the Advanced Institute for Management Research for financial support, Albert Bollard, Max Floetotto and John Van Reenen for helpful comments, and Pedro Castro, Rebecca Homkes, Stephen Dorgan and John Dowdy for their help with the development of the survey. The views expressed herein are those of the author(s) and do not necessarily reflect the views of the National Bureau of Economic Research.

NBER working papers are circulated for discussion and comment purposes. They have not been peerreviewed or been subject to the review by the NBER Board of Directors that accompanies official NBER publications.

(C) 2008 by Nicholas Bloom, Christos Genakos, Ralf Martin, and Raffaella Sadun. All rights reserved. Short sections of text, not to exceed two paragraphs, may be quoted without explicit permission provided that full credit, including (C) notice, is given to the source. 
Modern Management: Good for the Environment or just Hot Air?

Nicholas Bloom, Christos Genakos, Ralf Martin, and Raffaella Sadun

NBER Working Paper No. 14394

October 2008

JEL No. L26,L6,M11,M12,Q40,Q41

\begin{abstract}
$\underline{\text { ABSTRACT }}$
We use an innovative methodology to measure management practices in over 300 manufacturing firms in the UK. We then match this management data to production and energy usage information for establishments owned by these firms. We find that establishments in better managed firms are significantly less energy intensive. They use less energy per unit of output, and also in relation to other factor inputs. This is quantitatively substantial: going from the 25th to the 75th percentile of management practices is associated with a $17.4 \%$ reduction in energy intensity. This negative relationship is robust to a variety of controls for industry, location, technology and other factor inputs. Better managed firms are also significantly more productive. One interpretation of these results is that well managed firms are adopting modern lean manufacturing practices, which allows them to increase productivity by using energy more efficiently. This suggests that improving the management practices of manufacturing firms may help to reduce greenhouse gas emissions.
\end{abstract}

Nicholas Bloom

Stanford University

Department of Economics

579 Serra Mall

Stanford, CA 94305-6072

and NBER

nbloom@stanford.edu

Christos Genakos

Cambridge University

Selwyn College

Grange Road

Cambridge, CB3 9DQ

United Kingdom

cg370@cam.ac.uk
Ralf Martin

Centre for Economic Performance

London School of Economics

Houghton Street

London WC2A 2AE

R.Martin@1se.ac.uk

Raffaella Sadun

Centre for Economic Performance

London School of Economics

Houghton Street

London WC2A 2AE

R.Sadun@1se.ac.uk 


\section{Introduction}

A growing literature is pointing to differences in management practices as an important factor in explaining variations in productivity across firms and countries ${ }^{1}$. In this paper, we examine how the quality of management relates to the energy intensity of firms, a key driver of the greenhouse gas and pollution levels. The theoretical relationship between management practices and energy intensity is $a$ priori ambiguous. On the one hand, better managed firms should be able to reduce energy use through more efficient production techniques. On the other hand, the higher productivity that good management involves may also require greater capital utilization, and potentially higher energy usage. In this paper we assemble the first data set on management practices and energy intensity to investigate this relationship.

Based on cross country data, it appears that better management practices are associated with greater energy intensity. Figure 1 plots the $\mathrm{CO} 2$ pollution intensity across fifteen countries against the average quality of management (based on the Bloom and Van Reenen (2007) methodology and described in section 2 below), showing an apparently positive correlation, suggesting that well managed firms may pollute more. Particularly notable in this context is the performance of the US being a top ranked in both managerial quality and energy intensity. Of course a number of other variables, such as the level of regulation or industrial development, also differ across these countries, which may induce a spurious correlation between management practices and pollution. Hence, to examine this correlation more carefully it is important to look across firms within a particular country, thereby holding constant those common country-wide factors.

In this paper we match firm-level information on management practices to production and energy usage data from the UK business census for the establishments owned by these firms. The energy usage data from the census allows us to undertake the first evaluation of the firm level association between management practices and energy utilization. We find a robust negative correlation between management practices and energy intensity. In other words, better managed firms are less energy intensive, which as we discuss in Section 3 is robust to a large number of additional controls. Figure 2 plots this cross firm scatter plot of management practices against energy intensity showing a significant

\footnotetext{
${ }^{1}$ See, for example, Ichniowski, Shaw and Prenushi (1997), Black and Lynch (2001), Cappelli and Neumark (2001), Bertrand and Schoar (2003), Bartel, Ichniowski and Shaw (2007), Bloom and Van Reenen (2007) and Bloom, Sadun and Van Reenen (2007).
} 
Figure 1: CO2 Pollution Intensity and Management Practices Across Countries

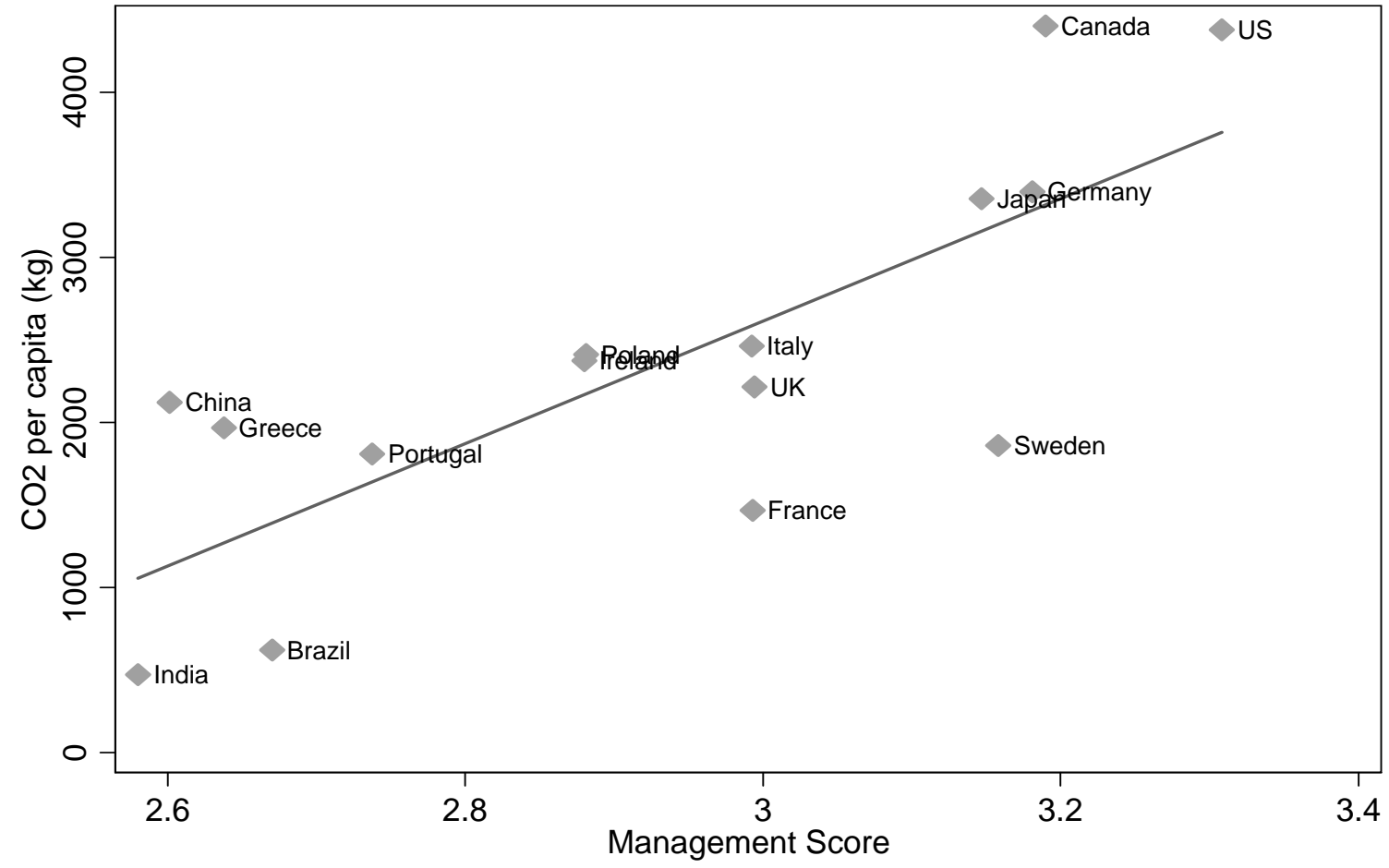

Notes: Data from the International Energy Agency and CEP management survey data. Horizontal axis reports average management score by country. Vertical axis reports the CO2 pollution per capita (kg per capita in 2005).

Figure 2: Energy intensity and management at the firm level (UK firms only)

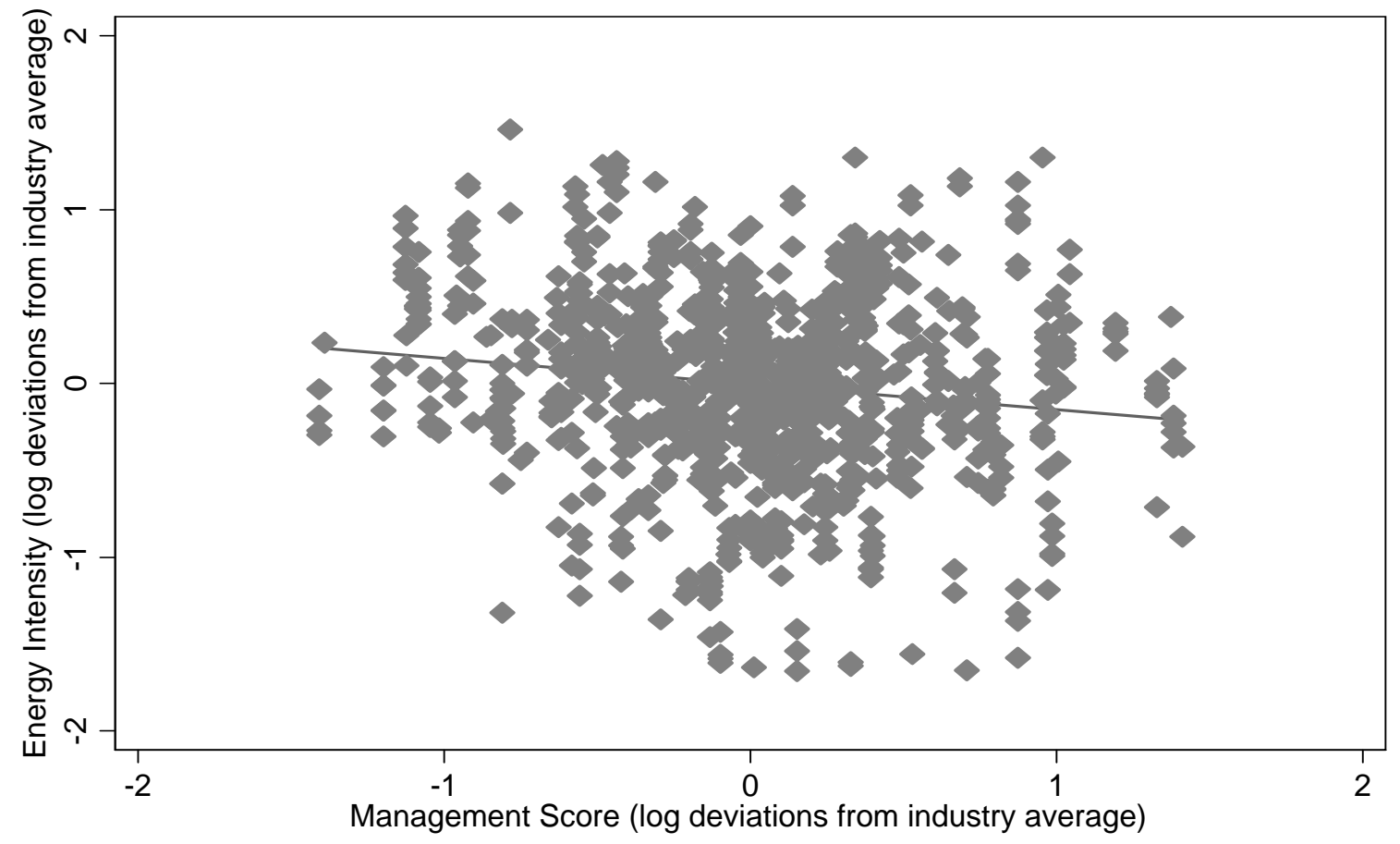

Notes: Data from census of production (ARD) and CEP management survey. The graph shows a scatter plot of the residuals of a regression of energy intensity on industry sector binary indicators on the residuals of a regression of the management score on the same industry binary indicators. 
negative correlation. Hence, this suggests that the positive cross-country correlation between energy intensity and better management is misleading, as it is driven by spurious correlations with other factors, such as the level of development. The magnitude of this negative cross-firm management correlation with energy intensity is quantitatively substantial. Improving management practices from the $25^{\text {th }}$ to the $75^{\text {th }}$ percentile is associated with a $17.4 \%$ reduction in energy intensity.

We also investigate the link between management practices and productivity, finding a strong positive correlation: improving the quality of management from the $25^{\text {th }}$ to $75^{\text {th }}$ percentile is associated with a $3.7 \%$ increase in total-factor productivity. Therefore, overall these results suggest that management practices that are associated with improved productivity are not linked to worse environmental performance. Rather, our results are broadly supportive of the idea that well run firms use energy inputs more efficiently, thereby increasing profitability and productivity, while at the same time reducing carbon emissions. We also find better managed firms use less materials in their production process, but more physical capital and more skilled labor.

A question that arises from our results is what could drive the negative correlation between energy intensity, management and economic performance in our firms? One explanation is that modern management practices minimize energy use. For example, Lean manufacturing, which is a widely adopted modern management technology developed by Toyota in the 1960s and 1970s, explicitly tries to reduce the waste of materials and energy. ${ }^{2}$ Another explanation is that the factors which induce firms to improve their management practices - like tougher product market competition or improved corporate governance - may also induce them to be more energy efficient in order to cut production costs.

Our results suggest that policies aimed at improving management practices - such as encouraging competition, reducing labor-market regulations and eliminating tax-incentives for family ownership may improve environmental outcomes. ${ }^{3}$ One example supporting this concept is the staggering energy

\footnotetext{
${ }^{2}$ See, for example, Womack et al. (1990).

${ }^{3}$ Of course the results might equally entail that environmental policies lead targeting firms lead to improvements in economic performance, for example Berman and Bui (2001) or Shadbegian and Gray (2005) and somewhat contrary, Greenstone (2002).
} 
inefficiency of the (old) Soviet block factories. These firms did not face product market competition, so had little incentive to economize on energy use.

The rest of the paper is organized as follows. In the next section we describe the two data sources used for this study. The third section provides the results and counterfactual analysis, whereas the last section concludes.

\section{Data}

The data used for the analysis is drawn from two different sources. The first source is the management survey conducted by the Centre for Economic Performance at the London School of Economics during the summer of 2006. This includes eighteen questions from which the overall management source is computed plus additional information on firms' characteristics and the interview process. The second source is the Census of Production data from the UK Office of National Statistics, which provides detailed information on establishments' production inputs.

\subsection{Management Data}

Overall, we surveyed almost 6,000 firms across 15 countries. Although in this paper we use only information on UK firms, in this section we describe the three key steps in collecting informative management practice data from firms across all countries.

\section{Scoring Management Practices}

First, to measure management requires codifying the concept of "good" or "bad" management into a measure applicable to different firms across the manufacturing sector. This is a challenging task as good management is difficult to define and is often contingent on a firm's environment. Our initial hypothesis was that, while characterizing every managerial practice as "good" or "bad" was extremely hard, there is a subset of practices that are common across manufacturing firms and for which such a characterization is informative. Our survey questions focus on such practices, and is built from a practice evaluation tool developed by a leading international management consultancy firm.

Our survey evaluation tool defines eighteen key management practices used by industrial firms and scores them from one (worst practice) to five (best practice). In Appendix A (Table A1) we detail these 
practices and the type of questions we asked in the same order as they appeared in the survey. Bloom and Van Reenen (2006) gives examples and more details on these practices.

These practices are grouped into four areas: operations (three practices), monitoring (five practices), targets (five practices) and incentives (five practices). The shop-floor operations section focuses on the introduction of lean manufacturing techniques, the documentation of processes improvements and the rationale behind the introduction of such improvements. The monitoring section focuses on the tracking of performance of individuals, reviewing performance (e.g. through regular appraisals and job plans), and consequence management (e.g. making sure that plans are kept and appropriate sanctions and rewards are in place). The targets section examines the type of targets (whether goals are simply financial or operational or more holistic), the realism of the targets (stretching, unrealistic or nonbinding), the transparency of targets (simple or complex) and the range and interconnection of targets (e.g. whether they are given consistently throughout the organization). Finally, the incentives section includes promotion criteria (e.g. purely tenure based or including an element linked to individual performance), pay and bonuses, and fixing or firing bad performers, where best practice is deemed the approach that gives strong rewards for those with both ability and effort. A subset of the practices has

similarities with those used in studies on Human Resource Management practices literature such as Ichniowski, Shaw and Prenushi (1997), Black and Lynch (2001) and Cappelli and Neumark (2001).

In our main econometric specifications we take the unweighted average across the scores as our primary measure of overall managerial quality. We also experimented with other weighting schemes based on factor analytic approaches, but none of our results changed in any fundamental way.

\section{Collecting Accurate Responses}

A second challenge is to obtain unbiased responses to these questions. The survey instrument was targeted at plant managers, who are typically senior enough to have an overview of management practices but not senior enough as to be detached from day-to-day operations of the enterprise. To obtain accurate information, we used a double-blind survey methodology. This consisted of two steps. First, the interviews were conducted by telephone without revealing to the managers that they were being scored. This enabled scoring to be based on the interviewer's evaluation of the firm's actual practices, rather than their aspirations, the manager's perceptions or the interviewer's impressions. 
Interviewers were specifically instructed to use open (i.e. "can you tell me how you promote your employees?"), rather than closed questions (i.e. “do you promote your employees on tenure [yes/no]?"). Furthermore, these questions targeted actual practices and examples, with the discussion continuing until the interviewer could make an accurate assessment of the firm's typical practices based on these examples. For each practice, the first question was broad and it was followed by detailed questions to fine-tune the scoring. For example, regarding the introduction of modern manufacturing practices, the initial question was: "Can you tell me about your manufacturing process?" and was followed by the more specific question: "How do you manage your inventory levels?".

The second step of the double-blind scoring methodology was that the interviewers did not know anything about the firm's financial information or performance in advance of the interview. This was achieved by selecting medium sized manufacturing firms and by providing only firm names and contact details to the interviewers (but no financial details). These smaller firms (the median size was 275 employees) would not be known by name and are rarely reported in the business media. The interviewers were specially trained graduate students from top European and U.S. business schools. All interviews were conducted in English.

Since each interviewer ran 85 interviews, on average, we can remove interviewer fixed effects from all empirical specifications. This helps to address concerns over inconsistent interpretation of categorical responses (see Manski, 2004), standardizing the scoring system. As an additional control for any residual potential survey noise, we collected detailed information on the interview process itself (number and type of prior contacts before obtaining the interviews, duration, time-of-day, date and dayof-the week), on the manager (gender, seniority, nationality, company and job tenure, internal and external employment experience and location). We refer to these variables as "noise controls", since their inclusion should help us control for measurement error.

\section{Obtaining Interviews with Managers}

Each interview took on average forty five minutes and was run during the summers of 2006 to 2008 from the Centre for Economic Performance at the London School of Economics. Overall, we obtained a relatively high response rate of $45 \%$, which was achieved through four steps. First, the interview was introduced as "a piece of work" without discussion of the firm's financial position or its company 
accounts, making it relatively uncontroversial for managers to participate. Interviewers did not discuss financials in the interviews, both to maximize the participation of firms but also to ensure our interviewers were truly "blind" on the firm's financial position. Also the fact that the questions were focused on firm's managerial practices meant that many managers, besides the plant manager, could be contacted $^{4}$. Second, practices were ordered to lead with the least controversial (shop-floor operations management) and finish with the most controversial (pay, promotions and firings). Third, interviewers' performance was closely monitored and explicitly incentivised. On the one hand, each team of interviewers (two or three persons) had a dedicated supervisor, providing on-the-spot training and advice, but also double-scoring most of the interviews conducted. On the other hand, interviewers' compensation was per interview conducted and there were also bonus payments on reaching team goals. These efforts led interviewers to be persistent when chasing any particular firm. Fourth, the written endorsement of the Governments, Central Banks and Employer Federations across the countries interviewed helped demonstrate to managers that this was an important exercise with official support.

We focused on medium sized manufacturing firms, randomly selecting firms with between 100 and 5,000 employees. Comparing the responding firms with those in the sampling frame, we found no evidence that the responders were systematically different on any of the performance measures to the non-responders. The only exception was on size, where our firms were slightly larger on average than those in the sampling frame.

The average management scores for the fifteen countries we interviewed are plotted in Figure 1 against the average level of $\mathrm{CO}_{2}$ produced per capita. The management scores are highest for the US, Canada and the traditional manufacturing countries like Germany, Japan and Sweden, intermediate for Northern Europe (UK, France, Italy and Poland) and low for Southern Europe and developing countries (Portugal, Greece, India, Brazil and China). The ordering for $\mathrm{CO}_{2}$ produced per capita is very similar, leading to a positive cross-country correlation between management practices and per capita energy use.

\footnotetext{
${ }^{4}$ We found no significant correlation between the number, type and time-span of contacts before an interview is conducted and the management score. This suggests while different managers may respond differently to the interview proposition, this does not appear to be directly correlated with their responses or the average management practices of the firm.
} 


\subsection{Census of Production Data}

The UK Office of National Statistics (ONS) maintains a register of all businesses in Britain called the Interdepartmental Business Register (IDBR). On the basis of this register the ONS runs a mandatory survey of UK businesses, the Annual Business Inquiry (ABI). ${ }^{5}$ Our firm level production data, the Annual Respondents Database (ARD), is derived from this survey. ${ }^{6}$ The ARD focuses mostly on medium and large firms, whereas smaller businesses with less than 250 employees are not surveyed every year but included into the sample on a random basis. The ARD sampled plants account for around $90 \%$ of total manufacturing employment in the UK.

\section{Matching the Census of Production data to the Management Survey data}

The CEP management survey provides data on 601 plants in Britain. Around 338 of these could be matched to the census production data. The match is not complete because the system of Company Register Numbers (CRN), which is the basis for the management survey, is maintained independently from the businesses registry that the production census is based upon. Although the ONS provides a lookup table between the two registers, there are a number of firms surveyed on their managerial practices that could not be matched to the production census. This is typically the case for smaller, less established firms.

Table B1 in the appendix reports descriptive statistics for the two samples of matched and un-matched firms. In terms of employment, matched firms have on average about 84 employees more than unmatched firms. They are also slightly older and have a higher management score. To the extent that this sample selection affects our results, we expect that it would introduce a downward bias by compressing the range of variation of firm performance (reducing the signal to noise ratio in the data). Appendix B provides further details of the matching process.

Because of stratified random sampling of smaller firms in the $\mathrm{ARD}^{7}$, we do not have production data for every firm in every year. Table 1 reports statistics on the firms we can use for productivity and

\footnotetext{
${ }^{5}$ Descriptions of the ABI can be found in Griffith (1999) and Criscuolo, Haskel and Martin (2003).

${ }^{6}$ This survey is the UK equivalent of the US Longitudinal Respondents Database (LRD).

${ }^{7}$ Firms with less than 250 employees are included on a random basis in the ARD whereas larger firms are sampled every year.
} 
Table 1 - Descriptive Statistics

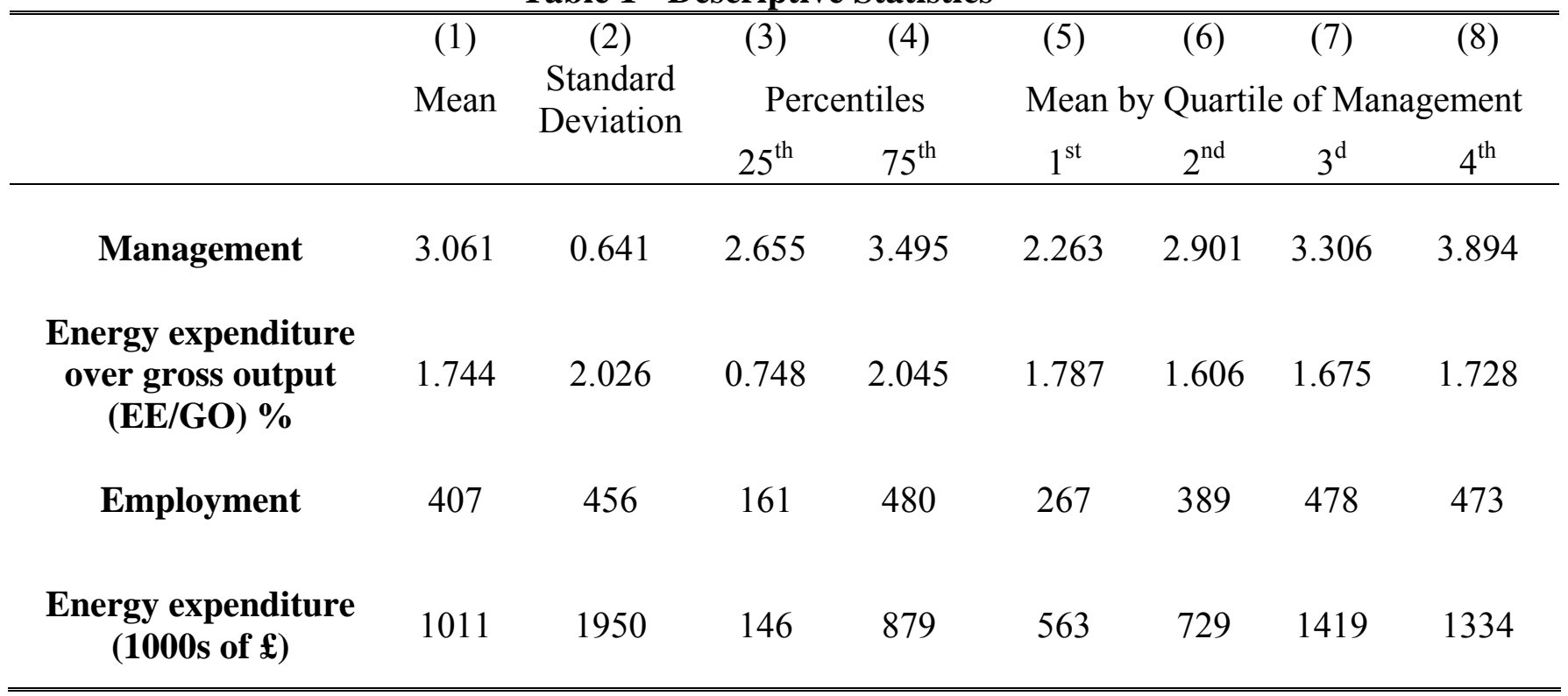

Notes: The above table provides summary statistics on some of the key variables of the matched census of production and management survey firm level data. Columns 5 to 8 report the means across quartiles of the management score distribution. For example, column 5 provides the average energy intensity (in row 2) of firms in the bottom quartile of the management score distribution. Statistics are based on 1046 observations from 272 firms across the years 1999 to 2004. 
energy intensity. In total we are able to use 1,046 observations corresponding to 272 firms between 1999 (first year with energy expenditure data) and 2004 (last available wave of the ARD).

\section{Results}

Our results are discussed in three parts. First, as a basic check on the data we confirm that our firmlevel management measure is significantly related to establishment level productivity, mirroring the results of Bloom and Van Reenen (2007). Second, we provide evidence showing that managerial quality is significantly related to lower levels of energy intensity. In other words, we demonstrate that the best managed firms are not only more productive, but also more efficient consumers of energy. Finally, we examine how management is related to the intensity in other production factors.

\subsection{Management practices and Productivity}

Consider the basic firm production function:

$$
g o_{i t}=\alpha_{l} l_{i t}+\alpha_{k} k_{i t}+\alpha_{i n} i n_{i t}+\alpha_{e} e_{i t}+\beta M_{i}+\gamma^{\prime} Z_{i t}+u_{i t}
$$

where $G O=$ real gross output (sales and inventory changes deflated with a sectoral producer price index), $L=$ labor, $K=$ capital, $I N=$ deflated expenditure on non-energy intermediate inputs (materials) and $E=$ deflated energy expenditure of firm $i$ at time $t$. Lower case letters denote natural logarithms, e.g. $l=\ln (L)$. The matrix $Z$ consists of a number of control variables that affect productivity, such as workforce characteristics $^{8}$ (the proportion of workers with a degree and the average hours worked), firm characteristics (firm age, whether the firm is listed), and a complete set of three digits industry binary indicators.

The crucial variable for us is management practices denoted by $M$. Our basic measure averages the eighteen individual management practices as a proxy for $M$. We experimented with a number of other approaches, such as using the primary factor, and found very similar results.

\footnotetext{
${ }^{8}$ We experimented with a wide range of workforce characteristics such as gender, worker age, education and unionization, finding our results robust to these additional controls.
} 
The most straightforward approach to estimating equation (1) is to simply run OLS on the panel with standard errors clustered by firm and assume that all the correlated heterogeneity is captured by the control variables. ${ }^{9}$ Table 2 investigates the association between firm performance and management practices. Column 1 simply reports an OLS specification controlling only for year and industry fixed effects. The management score is strongly positively and significantly associated with higher labor productivity (coefficient 0.490 , standard error 0.093). In column 2 we introduce our additional "noise controls", regional controls and firm characteristics. In line with our expectations these additional control variables reduce the measurement error in the management score and as a result the coefficient on management increases to 0.531 and is significant at the $1 \%$ level. In the rest of the table we introduce progressively more information on the other production factors. In column 3 we control for labor, whereas in columns 4 we also introduce capital, energy and materials controls. In column 5 we control for workforce skills as well. The coefficient on management, although diminishing in value, is always positive and significant at 0.044 . The economic magnitude of this effect is also substantial: improving the quality of management from the $25^{\text {th }}$ to $75^{\text {th }}$ percentile $(\Delta \mathrm{M}=0.840$ from Table 1$)$ is associated with a $3.7 \%(=0.044 \times 0.840)$ increase in total-factor productivity. These results parallel the findings of Bloom and Van Reenen (2007) indicating a positive and strong association between firm level management practices and establishment-level total factor productivity (TFP) across firms in four countries.

\subsection{Management practices and Energy Intensity}

Before analysing econometrically the relationship between managerial quality and energy intensity, it is informative to look at the raw distribution non-parametrically. Figure 3 plots the kernel density of energy expenditure over gross output for the best managed (top quartile) versus the worst (bottom quartile) managed firms. Two key facts become evident from this graph. First, there are more well managed firms that consume energy less intensively ("fatter" left tail of the distribution), and second, their whole distribution is to the left of that of the worst managed firms, indicating lower energy intensity overall.

\footnotetext{
${ }^{9}$ A large literature is concerned with endogeneity and biases in this kind of regression (see Griliches Mairesse 1996 for a summary.) We examine the robustness of our main results with respect to issue by implementing a control function approach (Olley and Pakes, 1996; Levinsohn and Petrin 2003; Martin, 2008). These results are available on request.
} 
Table 2 - Management Practices and Productivity

\begin{tabular}{|c|c|c|c|c|c|}
\hline & (1) & (2) & (3) & (4) & $(5)$ \\
\hline & \multicolumn{5}{|c|}{$\log$ (Gross Output) } \\
\hline Management & $\begin{array}{c}0.490 * * * \\
(0.093)\end{array}$ & $\begin{array}{c}0.531 * * * \\
(0.101)\end{array}$ & $\begin{array}{c}0.128 * * \\
(0.059)\end{array}$ & $\begin{array}{c}0.043 * * \\
(0.021)\end{array}$ & $\begin{array}{c}0.044 * * \\
(0.020)\end{array}$ \\
\hline Labor & & & $1.035 * * *$ & $0.243 * * *$ & $0.247 * * *$ \\
\hline $\log$ (number workers) & & & $(0.048)$ & $(0.029)$ & $(0.028)$ \\
\hline Capital & & & & $0.084 * * *$ & $0.084 * * *$ \\
\hline $\log$ (capital stock) & & & & $(0.023)$ & $(0.021)$ \\
\hline Materials - Energy & & & & $0.654 * * *$ & $0.651 * * *$ \\
\hline $\log$ (material - energy expenditure) & & & & $(0.035)$ & $(0.034)$ \\
\hline Energy & & & & 0.029 & 0.027 \\
\hline $\log$ (energy expenditure) & & & & $(0.019)$ & $(0.018)$ \\
\hline Share of High Skilled & & & & & $0.017 * *$ \\
\hline $\log$ (share of employees with degree) & & & & & $(0.008)$ \\
\hline Three digit sector controls & yes & yes & yes & yes & yes \\
\hline Age controls & no & yes & yes & yes & yes \\
\hline Noise controls & no & yes & yes & yes & yes \\
\hline Region controls & no & yes & yes & yes & yes \\
\hline Observations & 1046 & 1046 & 1046 & 1046 & 1046 \\
\hline Firms & 272 & 272 & 272 & 272 & 272 \\
\hline
\end{tabular}

Source: Authors' calculations based on census production (ARD) and CEP management survey data.

Notes: The dependent variable in all regressions is the logarithm of gross output. All columns include a full set of year binary indicators. "Management" is the average scores across the eighteen questions on management practices from the CEP management survey; output and factor input variables (labor, capital, materials, energy) are from the census production data (ARD). Noise controls are a set of variables capturing interview characteristics: duration and time of the interview, the gender of the interviewee, the reliability and competence of the interviewee as perceived by the interviewer and binary indicators for each interviewer. Standard errors clustered at the firm level (i.e. robust to heteroskedasticity and autocorrelation of unknown form) are reported in parenthesis below coefficients: *significant at $10 \% ; *$ significant at $5 \%$; ***significant at $1 \%$. 
Figure 3: Management Practices and Energy Intensity

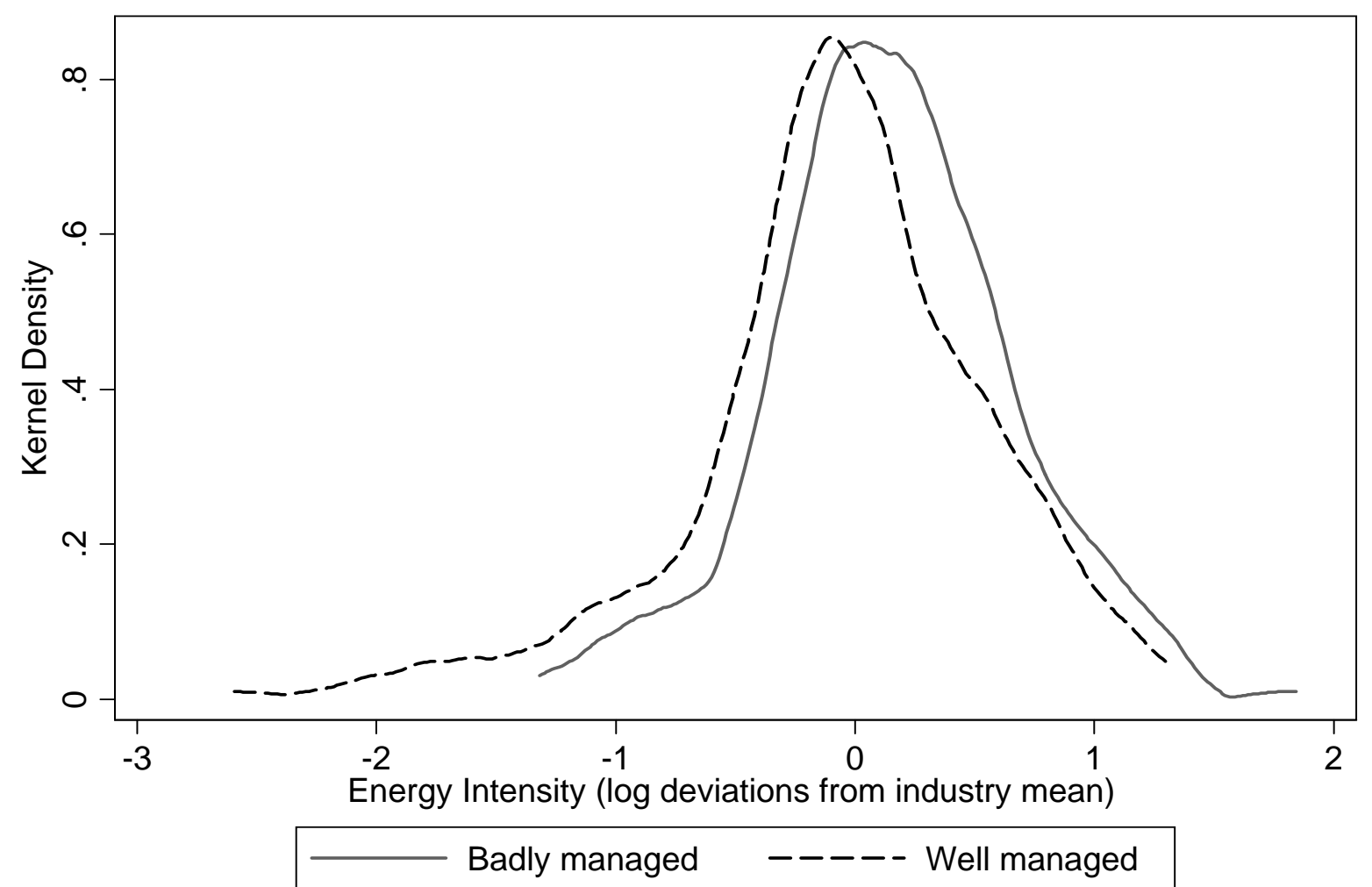

Notes: Data from the Census production (ARD) and CEP management survey data. The graph shows kernel density plots of (the logistic transformation of) energy expenditure over gross output for the sample of firms with management score in the bottom quartile (badly managed) and the top quartile (well managed) 
To investigate the relationship between management practices and energy intensity of production in more detail, we consider the following specification:

$$
(E E / G O)_{i t} \times 100=\alpha_{i n} g o_{i t}+\alpha_{l} l_{i t}+\alpha_{k} k_{i t}+\beta M_{i}+\gamma^{\prime} Z_{i t}+u_{i t}
$$

where $E E / G O \times 100=$ energy expenditure over gross output in percentage terms, $G O=$ gross output (sales and inventory changes), $L=$ labor, $K=$ capital, and $M=$ our management practices score for firm $i$ at time $t$. Lower case letters again denote natural logarithms, e.g. $l=\ln (L)$. The matrix $Z$ consists of a number of control variables that affect productivity, such as workforce characteristics (the proportion of workers with a degree), firm characteristics (firm age), and a complete set of three digits industry binary indicators.

Table 3 reports the results from this specification. Column 1 simply regresses energy intensity defined as the energy share of gross-output - on management practices, controlling for year and industry differences. The management coefficient is strongly negative and significant, indicating that well managed firms consume energy more efficiently given their level of output. In column 2 the introduction of our "noise controls" and firm characteristics renders the management coefficient stronger and more statistically significant. In column 3 we introduce (log) gross output to control for possible scale effects. The coefficient on gross output is negative which is consistent with scale effects - i.e. larger firms requiring less energy per unit of output - but not significant. The coefficient on management reduces slightly from -0.394 to -0.326 but is still significant. In columns 4 to 6 we experiment using labour and capital as proxies for size. The management coefficient is not significantly affected by their inclusion although its point estimate is somewhat larger than in column 3 .

In columns 7 and 8 we re-introduce gross output. Once both gross output and employment or capital are introduced, the former becomes significantly negative, whereas capital and labour become positive, although not significant. This suggests that there are two opposing effects. On the one hand, there is a scale effect: larger output means that energy intensity reduces (there appear to be energy "economies of scale"). On the other hand, more labour or capital intensive firms require more energy. However, irrespective of this heterogeneity, better managed firms are always significantly less energy intensive. The economic magnitude of these coefficients is large. For example, the coefficient of -0.362 in 
Table 3 - Management Practices and Energy Intensity

\begin{tabular}{|c|c|c|c|c|c|c|c|c|c|}
\hline & $(1)$ & $(2)$ & (3) & (4) & $(5)$ & $(6)$ & $(7)$ & $(8)$ & (9) \\
\hline & \multicolumn{9}{|c|}{ Energy Expenditure over gross output (EE/GO x 100) } \\
\hline Management & $\begin{array}{c}-0.225 * * \\
(0.113)\end{array}$ & $\begin{array}{c}-0.394 * * \\
(0.154)\end{array}$ & $\begin{array}{c}-0.326^{* *} \\
(0.161)\end{array}$ & $\begin{array}{c}-0.351 * * \\
(0.160)\end{array}$ & $\begin{array}{c}-0.375 * * \\
(0.171)\end{array}$ & $\begin{array}{c}-0.365 * * \\
(0.171)\end{array}$ & $\begin{array}{c}-0.361 * * \\
(0.168)\end{array}$ & $\begin{array}{c}-0.362 * * \\
(0.167)\end{array}$ & $\begin{array}{c}-0.370 * * \\
(0.167)\end{array}$ \\
\hline Gross output & & & -0.127 & & & & $-0.336 * *$ & $-0.359 *$ & $-0.387 * *$ \\
\hline $\log$ (gross output) & & & $(0.109)$ & & & & $(0.164)$ & $(0.197)$ & $(0.193)$ \\
\hline Labor & & & & -0.110 & & -0.164 & & 0.040 & 0.055 \\
\hline $\log$ (number workers) & & & & $(0.132)$ & & $(0.186)$ & & $(0.221)$ & $(0.214)$ \\
\hline Capital & & & & & -0.031 & 0.055 & 0.233 & 0.230 & 0.243 \\
\hline $\log$ (capital stock) & & & & & $(0.122)$ & $(0.172)$ & $(0.196)$ & $(0.199)$ & $(0.194)$ \\
\hline Share of High Skilled & & & & & & & & & 0.023 \\
\hline $\log$ (share of employees with degree) & & & & & & & & & $(0.072)$ \\
\hline Three digit sector controls & yes & yes & yes & yes & yes & yes & yes & yes & yes \\
\hline Age controls & no & yes & yes & yes & yes & yes & yes & yes & yes \\
\hline Noise controls & no & yes & yes & yes & yes & yes & yes & yes & yes \\
\hline Region controls & no & yes & yes & yes & yes & yes & yes & yes & yes \\
\hline Observations & 1046 & 1046 & 1046 & 1046 & 1046 & 1046 & 1046 & 1046 & 1046 \\
\hline Firms & 272 & 272 & 272 & 272 & 272 & 272 & 272 & 272 & 272 \\
\hline
\end{tabular}

Source: Authors' calculations based on census production (ARD) and CEP management survey data.

Notes: The dependent variable in all regressions is energy expenditure over gross output. All columns include a full set of year binary indicators. "Management" is the average scores across the eighteen questions on management practices from the CEP management survey; output and factor input variables (labor, capital, materials, energy) are from the census production data (ARD). Column 3 introduces gross output to control for size. A potential issue is that instead of output in volume units, we only observe revenue. We therefore also include the other production factors in subsequent columns to correct for any possible scale effects. Noise controls are a set of variables capturing interview characteristics: duration and time of the interview, the gender of the interviewee, the reliability and competence of the interviewee as perceived by the interviewer and binary indicators for each interviewer. Standard errors clustered at the firm level (i.e. robust to heteroskedasticity and autocorrelation of unknown form) are reported in parenthesis below coefficients: *significant at $10 \%$; $*$ significant at $5 \%$; *** significant at $1 \%$. 
column 8 suggests that at the sample mean of EE/GO (1.744) improving managerial practices from the $25^{\text {th }}$ to the $75^{\text {th }}$ percentile (an increase in management of 0.840 ) is associated with a $17.4 \%$ reduction in energy intensity $\left(\beta_{\mathrm{M}} \times \Delta \mathrm{M} /(\mathrm{EE} / \mathrm{GO})=-0.362 \times 0.840 / 1.744 \%=-17.4 \%\right)$. Finally, in column 9 we include controls for skills, as an additional proxy for firm type. The negative correlation between energy intensity and management practices persists and continues to be significant.

A number of concerns might arise with these results. First, our results imply nothing on the causality of the relationship between management and energy efficiency. It is quite possible this correlation is driven by other unobserved factors, for example that hiring management consultants helps to improve management practices and reduce energy usage. The evidence we have is merely suggestive, in that well managed firms appear to be robustly more energy efficient. As the first study of its kind to show this, we believe this is an interesting result in itself. We are also running field experiments in India to change the management practices of a randomly selected group of textiles firms to evaluate the causal impact of this on energy intensity.

Second, because in our firm level data we do not have firm specific price information, our gross output measure captures both variations in actual output and variations in output price. Better managed firms might plausibly be able to charge higher prices for their products, increasing the mark-up and reducing factor cost-shares. In appendix C (Table C1) we therefore repeat the regressions from Table 3 using energy expenditure over variable costs (expenditure on labour and intermediates, VCOST) as our dependent variable. None of our results from Table 3 change in any fundamental way. To ensure that our results are driven by variations in energy expenditure rather than variation in the denominator (GO or VCOST), in Table C2 we also report similar regressions where we use (log) energy expenditure (log EE) as the dependent variable. In columns 1 and where we do not include any controls for firm size this leads to a positive and significant coefficient, because better managed firms are larger on average. With size controls from column 3 onward, the management coefficient turns significantly negative in line with our earlier results. Finally, we examine our results using log energy shares (Table C3). The main justification for using just energy shares in tables 2 and 3 is that such an approach is consistent with the popular translog factor estimation (Christensen, Jorgenson, Lau, 1971; Christensen, Greene, 1976). However, as it is evident from the table, this choice is not essential for our basic correlation between managerial practices and energy intensity. 


\subsection{Quantifying the Effect of Management on Energy Intensity}

While we can not interpret our results as causal, it is nevertheless interesting to explore their economic magnitude. For this purpose we conduct the following counterfactual experiment: what reduction in energy usage would occur if we increased managerial practices in a firm from the lowest to the top quartile, assuming that its energy intensity change in line with the sample average correlation? And in a similar spirit: what would be the resulting reduction in energy usage if the average UK firm - which has a very similar average management score to the average firm in Europe ${ }^{10}$ - were to experience an improvement in its management that would elevate it to the average US firm?

Notice that we have no direct information on the greenhouse gas pollution. However, if we are willing to assume that there is a constant rate of carbon pollution associated with every unit spent on energy, then the percentage impact on pollution will be equal to the percentage impact on expenditure.

We calculate the counterfactual percentage change in energy expenditure as follows:

$$
\frac{E E^{C F}-E E}{E E}=\beta_{M} \Delta M /\left(\frac{E E}{G O}\right)
$$

where $\mathrm{EE}^{\mathrm{CF}}$ is the counterfactual energy expenditure. In other words, the percentage impact on energy expenditure is equal to the change in management quality times the coefficient on management in a factor share regression, divided by energy intensity.

Table 4 reports the results from a number of counterfactual scenarios. The first scenario in row one considers the impact on energy intensity of moving from the bottom quartile management score (2.263) to the top quartile management score (3.894), an improvement of 1.631. The coefficient on management from column 8 in Table 3 is $\beta_{\mathrm{M}}=-0.362$. Multiplying by the 1.631 management change and dividing by the bottom quartile energy intensity of $1.787 \%$ we get a one third reduction of energy expenditure, 33\%. Rows 2 to 3 report the results of similar calculations for the other two quartiles. Perhaps most interestingly is the implied aggregate effect on energy usage, calculated as the sum of the percentage change in energy expenditure (column 5) weighted by the share of energy consumption for

\footnotetext{
${ }^{10}$ In the sample our UK average management score is 2.97 while the average across our firm sample from Europe (France, Germany, Greece, Ireland, Italy, Poland, Portugal and Sweden) is 2.98.
} 
Table 4 - Counterfactual Scenarios

\begin{tabular}{|c|c|c|c|c|c|}
\hline & (1) & (2) & (3) & (4) & (5) \\
\hline & $\begin{array}{c}\beta_{\mathrm{M}} \\
\underset{\text { management }}{\text { coefficient }}\end{array}$ & $\begin{array}{c}\Delta \mathrm{M} \\
\text { change in } \\
\begin{array}{c}\text { management } \\
\text { score }\end{array}\end{array}$ & $\begin{array}{l}\text { EE share } \\
\text { share of } \\
\text { aggregate } \\
\text { energy } \\
\text { consumption }\end{array}$ & $\begin{array}{c}\mathrm{EE} / \mathrm{GO}[\%] \\
\% \text { energy } \\
\text { expenditure } \\
\text { over gross } \\
\text { output } \\
\end{array}$ & $\begin{array}{c}\left(\mathrm{EE}^{\mathrm{CF}}-\mathrm{EE}\right) / \mathrm{EE}[\%] \\
\% \text { change in energy } \\
\text { expenditure }\end{array}$ \\
\hline $\begin{array}{l}\text { Moving from bottom } \\
\text { quartile to top quartile }\end{array}$ & -0.362 & 1.631 & 0.139 & 1.787 & -33.040 \\
\hline $\begin{array}{l}\text { Moving from second } \\
\text { quartile to top quartile }\end{array}$ & -0.362 & 0.993 & 0.180 & 1.606 & -22.383 \\
\hline $\begin{array}{l}\text { Moving from third quartile } \\
\text { to top quartile }\end{array}$ & -0.362 & 0.588 & 0.351 & 1.675 & -12.708 \\
\hline $\begin{array}{l}\text { Moving UK average to } \\
\text { equal US average }\end{array}$ & -0.362 & 0.362 & & 1.744 & -7.514 \\
\hline
\end{tabular}

Source: Authors' calculations based on census production (ARD) and CEP management survey data.

Notes: The table reports results of the various counterfactual scenarios based on the results from Tables 1-3. The management coefficient in column 1 is taken from Table 3, column 8. Differences across quartiles in management scores and energy expenditure over gross output are taken from Table 1. Column 3 is based on energy expenditure values from Table 1. Last column is calculated based on the formula provided in the text. 
each quartile (column 3). Finally, in row 5 we examine the impact of a change in management quality corresponding to the average difference between the US and UK of $\Delta \mathrm{M}=0.362$ on the average UK firm; i.e. an energy expenditure over gross output of $1.744 \%$. This last scenario leads to a more modest $7.5 \%$ reduction in energy expenditure, suggesting the improving the management practices of firms in the UK and Europe could be associated with reductions in energy intensity of $5 \%$ to $10 \%$.

\subsection{Effect on other factors}

The analysis so far naturally raises questions about the factor intensity usage of other inputs: do better managed firms use all factor inputs less intensively, or substitute across different types of factor inputs? In summary, we find that better managed firms use less energy and materials, but a higher level of capital and (skilled) labor inputs.

Table 5 examines this by reporting factor intensity results for materials, capital and labor. Columns 1 and 2 report regressions of the intensity in intermediate inputs including energy, whereas columns 3 and 4 exclude energy from intermediates. All materials input regressions yield significantly negative coefficient for management although the results without energy lead to somewhat lower (in absolute terms) and less significant point estimates. Better managed firms use less materials and less energy in their production process. Columns 5 and 6 report results for labor intensity (measured by the total wage bill) and 7 and 8 for capital intensity (measured by the stock of tangible fixed-assets) ${ }^{11}$. The results from these last four columns strongly indicate that better managed firms are more labor and capital intensive even when controlling for size by including (log) gross output. This higher labour intensity appears to be due to a higher skill content of the workers, leading to a higher total wage bill. ${ }^{12}$

\footnotetext{
${ }^{11}$ To compute cost shares for capital we would have to make assumptions about depreciation and interest rates to derive the user cost of capital. To avoid that we simply examine the ratio between capital stocks and output or costs. As it is not bounded between zero and one, as the cost shares, we report results in log terms.

12 Across the sample of all 601 UK firms covered by the CEP management survey the correlations (and their p-value) between management and the $\log (\%$ of employees with a degree $)$ is $0.127(0.003)$ and between management and the $\log ($ average wage) is $0.171(0.000)$. The same figures for the full sample of 5,198 firms from all 12 countries in the survey are $0.2607(0.000)$ and $0.309(0.000)$.
} 
Table 5 - Factor Intensities

\begin{tabular}{|c|c|c|c|c|c|c|c|c|}
\hline & $\begin{array}{c}(1) \\
\text { ME/GO } \\
\text { materials } \\
\text { expenditure } \\
\text { over gross } \\
\text { output }\end{array}$ & $\begin{array}{c}(2) \\
\text { ME/VCOST } \\
\text { materials } \\
\text { expenditure } \\
\text { over variable } \\
\text { costs }\end{array}$ & $\begin{array}{c}(3) \\
\text { (ME-EE)/GO } \\
\text { materials } \\
\text { minus energy } \\
\text { expenditure } \\
\text { over gross } \\
\text { output }\end{array}$ & $\begin{array}{c}\text { (4) } \\
\text { (ME-EE)/VCOST } \\
\text { materials minus } \\
\text { energy expenditure } \\
\text { over variable costs }\end{array}$ & $\begin{array}{c}(5) \\
\text { LE/GO } \\
\text { labor } \\
\text { expenditure } \\
\text { over gross } \\
\text { output }\end{array}$ & $\begin{array}{c}(6) \\
\text { LE/VCOST } \\
\text { labor } \\
\text { expenditure } \\
\text { over variable } \\
\text { costs }\end{array}$ & $\begin{array}{c}(7) \\
\ln (\mathrm{K} / \mathrm{GO}) \\
\text { capital } \\
\text { expenditure } \\
\text { over gross } \\
\text { output }\end{array}$ & $\begin{array}{c}(8) \\
\ln (\mathrm{K} / \mathrm{VCOST}) \\
\text { capital } \\
\text { expenditure } \\
\text { over variable } \\
\text { costs }\end{array}$ \\
\hline Management & $\begin{array}{c}-2.849 * * \\
(1.447)\end{array}$ & $\begin{array}{l}-2.760 * * \\
(1.243)\end{array}$ & $\begin{array}{l}-2.488 * \\
(1.454)\end{array}$ & $\begin{array}{l}-2.372 * \\
(1.292)\end{array}$ & $\begin{array}{l}1.642 * \\
(0.973)\end{array}$ & $\begin{array}{l}2.760 * * \\
(1.243)\end{array}$ & $\begin{array}{l}0.147 * * \\
(0.058)\end{array}$ & $\begin{array}{c}0.157 * * * \\
(0.056)\end{array}$ \\
\hline $\begin{array}{l}\text { Gross output } \\
\log \text { (gross output) } \\
\text { Capital } \\
\log \text { (capital stock) }\end{array}$ & $\begin{array}{c}2.703 \\
(1.676) \\
1.250 \\
(1.607)\end{array}$ & $\begin{array}{c}6.871 * * * \\
(1.478) \\
-1.694 \\
(1.327)\end{array}$ & $\begin{array}{c}3.039 * \\
(1.642) \\
1.018 \\
(1.596)\end{array}$ & $\begin{array}{c}7.203 * * * \\
(1.470) \\
-1.912 \\
(1.342)\end{array}$ & $\begin{array}{c}-7.267 * * * \\
(1.165) \\
2.563 * * \\
(1.010)\end{array}$ & $\begin{array}{c}-6.871 * * * \\
(1.478) \\
1.694 \\
(1.327)\end{array}$ & $\begin{array}{c}-0.102 * * \\
(0.039)\end{array}$ & $\begin{array}{c}-0.087 * * \\
(0.038)\end{array}$ \\
\hline $\begin{array}{l}\text { Three digit sector } \\
\text { controls }\end{array}$ & yes & yes & yes & yes & yes & yes & yes & yes \\
\hline Age controls & yes & yes & yes & yes & yes & yes & yes & yes \\
\hline Noise controls & yes & yes & yes & yes & yes & yes & yes & yes \\
\hline Region controls & yes & yes & yes & yes & yes & yes & yes & yes \\
\hline Observations & 1046 & 1046 & 1046 & 1046 & 1046 & 1046 & 1046 & 1046 \\
\hline Firms & 272 & 272 & 272 & 272 & 272 & 272 & 272 & 272 \\
\hline
\end{tabular}

Source: Authors' calculations based on census production (ARD) and CEP management survey data.

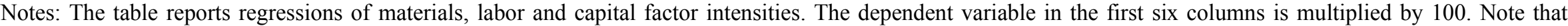

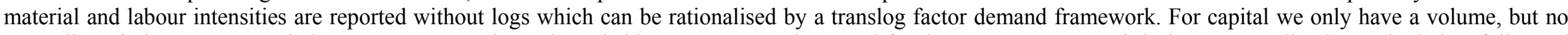

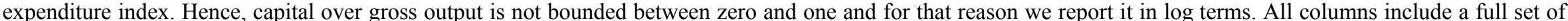

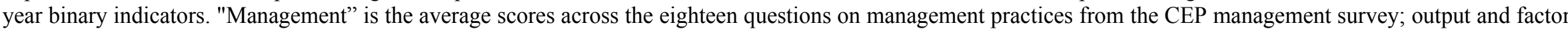

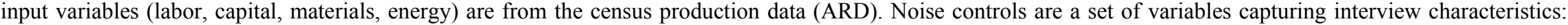

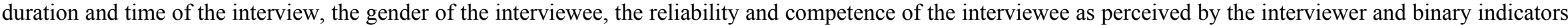

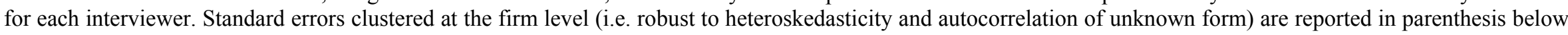
coefficients: *significant at $10 \% ; * *$ significant at $5 \%$; *** significant at $1 \%$. 


\subsection{Effect on $\mathrm{CO} 2$ and energy quantity}

So far we implicitly assumed that energy prices do not vary systematically between firms after controlling for size, so that variations in energy expenditure intensity directly translate into variations in energy usage and pollution of the key greenhouse gas, $\mathrm{CO} 2$. For a highly integrated energy market such as the UK this does not seem unreasonable. Nevertheless in this section we provide some further evidence to support this assumption. Specifically, we confirm our key findings using quantity data on energy usage from the Quarterly Fuels Inquiry (QFI). ${ }^{13}$ The QFI is a survey run by the UK Office of National Statistics, which inquires about the usage of a variety of different fuels at the firm level. However, its sample size is about a tenth of the ARD used for the results above. As a result, the overlap between QFI and management survey data sample is fairly small with less than 300 observations. For this reason we did not use it for our main analysis, but it nevertheless provides a useful cross-validation of our main results.

Table 6 contains the main QFI results. Column 1 looks simply at kWh of energy used and column 2 looks at the ratio between $\mathrm{kWh}$ and gross output. In either case we find a significantly negative relationship with management, i.e. better management firms use less kWh of energy. Columns 3 and 4 repeat the exercise with $\mathrm{CO} 2$ (we compute $\mathrm{CO} 2$ emissions on the basis of the quantity information on different fuel types and common conversion factors for the carbon content of fuels as reported in the appendix, table D1). Again we find a negative relationship, which is significant at the $10 \%$ level.

\section{Conclusions}

In this paper we match information that quantifies the firm-level managerial quality, following the methodology developed by Bloom and Van Reenen (2007), to their establishment-level data in the UK census of production. Since the census data contains energy usage data, this allows us to undertake the first evaluation of the firm level association between management practices and energy intensity. We find a robust negative correlation between management practices and energy intensity. Better managed firms are more energy intensive, with the correlation substantial in magnitude - improving management levels from the $25^{\text {th }}$ to the $75^{\text {th }}$ percentile is associated with a $17.4 \%$ reduction in energy intensity. We also find a strong correlation between better management practices and establishment-

\footnotetext{
${ }^{13}$ For more details on the QFI see Martin (2005).
} 
Table 6 - Quantity measures

\begin{tabular}{lcccc}
\hline \hline & $\begin{array}{c}(1) \\
\mathbf{l n}(\mathbf{k W h})\end{array}$ & $\begin{array}{c}(2) \\
\mathbf{l n}(\mathbf{k W h} / \mathbf{G O}) \\
\mathbf{l o g} \text { of } \mathbf{k W h} \text { over } \\
\text { gross output }\end{array}$ & $\begin{array}{c}(3) \\
\mathbf{l n}(\mathbf{C O 2}) \\
\begin{array}{c}\mathbf{l o g} \text { of carbon } \\
\text { dioxide }\end{array}\end{array}$ & $\begin{array}{c}(4) \\
\mathbf{l n}(\mathbf{C O 2 / G O}) \\
\text { log of carbon } \\
\text { dioxide over gross } \\
\text { output }\end{array}$ \\
\hline Management & $-0.332^{* *}$ & $-0.332^{* *}$ & $-0.288^{*}$ & $-0.288^{*}$ \\
Gross output & $(0.159)$ & $(0.159)$ & $(0.149)$ & $(0.149)$ \\
log (gross output) & 0.067 & $-0.933^{* * *}$ & 0.074 & $-0.926^{* * *}$ \\
Capital & $(0.052)$ & $(0.052)$ & $(0.047)$ & $(0.047)$ \\
log (capital stock) & $0.919^{* * *}$ & $0.919^{* * *}$ & $0.913^{* * *}$ & $0.913^{* * *}$ \\
\hline Three digit sector & $(0.048)$ & $(0.048)$ & $(0.045)$ & $(0.045)$ \\
controls & yes & yes & yes & yes \\
Age controls & yes & yes & yes & yes \\
Noise controls & yes & yes & yes & yes \\
Region controls & yes & yes & yes & yes \\
\hline Observations & 3857 & 3857 & 3857 & 3857 \\
Firms & 1246 & 1246 & 1246 & 1246 \\
Observations with & 286 & 286 & 286 & 286 \\
management data & & & & \\
\hline \hline
\end{tabular}

Source: Authors' calculations based on census production (ARD), Quarterly Fuels Inquiry (QFI) and CEP management survey data.

Notes: The table reports regressions of $\mathrm{kWh}$ and carbon dioxide used in production. These variables are based on data from the Quarterly Fuels Inquiry (QFI). To compute CO2 values on the basis of energy quantities we use the conversion factors reported in table D1 of the appendix. The QFI has a much smaller sample than the production census data (ARD). Hence, the intersection of all three datasets lead to a sample of only about 300 firms. To identify all control variables we run all regressions on the full sample of firms with QFI information and include a dummy equal to one when the management information is missing. All columns include a full set of year binary indicators. "Management" is the average scores across the eighteen questions on management practices from the CEP management survey; output and factor input variables (labor, capital, materials, energy) are from the census production data (ARD). Noise controls are a set of variables capturing interview characteristics: duration and time of the interview, the gender of the interviewee, the reliability and competence of the interviewee as perceived by the interviewer and binary indicators for each interviewer. Standard errors clustered at the firm level (i.e. robust to heteroskedasticity and autocorrelation of unknown form) are reported in parenthesis below coefficients: *significant at $10 \%$;**significant at $5 \%$; *** significant at $1 \%$. 
level productivity, with a move from the $25^{\text {th }}$ to $75^{\text {th }}$ percentile of management associated with a $3.7 \%$ increase in total-factor productivity.

These results suggest that management practices that are associated with improved productivity are not linked to worse environmental performance. Rather, is broadly supportive of the idea that well run firms use energy inputs more efficiently, thereby increasing profitability and productivity while at the same time reducing carbon emissions. Future research will seek to evaluate the causal nature of the relationship between management practices and energy intensity by using field experiments to randomly change management practices and evaluate its impact on energy intensity. 


\section{Bibliography}

Bartel, A., Ichniowski, C., and Shaw, K. (2007). How does information technology affect productivity? plant-level comparisons of product innovation, process improvement, and worker skills. The Quarterly Journal of Economics, 122(4):1721-1758.

Berman, E. and Bui, L. (2001). Environmental regulation and productivity: Evidence from oil refineries. Review of Economics and Statistics, 83:498-510.

Bertrand, Marianne and Antoinette Schoar (2003), "Managing with Style: The Effect of Managers on Firm Policies", Quarterly Journal of Economics, CXVIII (4), 1169-1208.

Black, Sandra and Lisa Lynch (2001), "How to Compete: The Impact of Workplace Practices and Information Technology on Productivity", Review of Economics and Statistics, LXXXIII (3), 434-445.

Bloom, N., Sadun, R. and J. Van Reenen (2007), “Americans do IT better: multinationals and the US productivity miracle", NBER Working paper 13085.

Bloom, N., and J. Van Reenen (2006), "Measuring and Explaining Management Practices across Firms and Nations", Centre for Economic Performance Discussion Paper No. 716.

Bloom, N., and J. Van Reenen (2007), "Measuring and explaining management practices across firms and countries", Quarterly Journal of Economics, CXXII, 1341-1408.

Cappelli, P. and Neumark, D. (2001), "Do 'High Performance" Work Practices Improve EstablishmentLevel Outcomes?”, Industrial and Labor Relations Review, July 2001, pp.737-775.

Christensen, L.R., D.W. Jorgenson and L.J. Lau (1971), "Conjugate Duality and the Transcendental Logarithmic Production Function”, Econometrica, 39, 255-256.

Christensen, L. R. and W.H. Greene (1976), "Economies of Scale in U.S. Electric Power Generation", Journal of Political Economy, Vol. 84, No. 4, pp. 655-676.

Criscuolo, C., Haskel, J. and Martin, R. (2003), "Building the evidence base for productivity policy using business data linking”, Economic Trends, November 2003.

Griffith, R. (1999), "Using the ARD establishment level data to look at foreign ownership and productivity in the UK", Economic Journal, 109:F416-F442.

Greenstone, M. (2002), "The impacts of environmental regulations on industrial activity: Evidence from the 1970 and 1977 clean air act amendments and the census of manufactures", Journal of Political Economy, 110(6):1175-1219.

Griliches, Z. and Mairesse, J. (1995). Production functions: The search for identification. NBER Working Paper, (5067). 
Ichniowski, C., K. Shaw and G. Prenushi (1997), "The Effects of Human Resource Management: A Study of Steel Finishing Lines”, American Economic Review, LXXXVII (3), 291-313.

Levinsohn, J. and Petrin, A. (2003). Estimating production functions using inputs to control for unobservables. Review of Economic Studies, 70(2)(243):317-342.

Manski, C. (2004), “Measuring expectations”, Econometrica, LXXII (5), 1329-1376.

Martin, R. (2005), “UK plant level energy data”, DTI Economics Papers.

Martin, R. (2008), "Productivity dispersion, competition and productivity measurement", Centre for Economic Performance Discussion Paper No. 692.

Olley, S. and Pakes, A. (1996). The dynamics of productivity in the telecomunications equipment industry. Econometrica, 64:1263-97.

Shadbegian, R. J., Gray, W. B., August (2005), "Pollution abatement expenditures and plant-level productivity: A production function approach”, Ecological Economics, 54 (2-3), 196-208.

Womack, J. P., Jones D. T., and D. Roos (1990), The Machine That Changed the World: The Story of Lean Production, New York: Rawson and Associates. 
APPENDIX A: DETAILS OF THE SURVEY QUESTIONNAIRES

TABLE A1: Full list of management practices with examples of the questions asked

\begin{tabular}{|c|c|c|c|}
\hline Practice & $\begin{array}{l}\text { Practice } \\
\text { number }\end{array}$ & Practice type & Example of questions we asked \\
\hline $\begin{array}{l}\text { Modern manufacturing, } \\
\text { introduction }\end{array}$ & 1 & Operations & $\begin{array}{l}\text { a) Can you describe the production process for me? } \\
\text { b) What kinds of lean (modern) manufacturing processes have } \\
\text { you introduced? Can you give me specific examples? } \\
\text { c) How do you manage inventory levels? What is done to } \\
\text { balance the line? }\end{array}$ \\
\hline Modern manufacturing, rationale & 2 & Operations & $\begin{array}{l}\text { a) Can you take through the rationale to introduce these } \\
\text { processes? } \\
\text { b) What factors led to the adoption of these lean (modern) } \\
\text { management practices? }\end{array}$ \\
\hline Process documentation & 3 & Operations & $\begin{array}{l}\text { a) How would you go about improving the manufacturing } \\
\text { process itself? } \\
\text { b) How do problems typically get exposed and fixed? } \\
\text { c) Talk me through the process for a recent problem. } \\
\text { d) Do the staff ever suggest process improvements? }\end{array}$ \\
\hline Performance tracking & 4 & Monitoring & $\begin{array}{l}\text { a) Tell me how you track production performance? } \\
\text { b) What kind of Key Performance Indicators (KPIs) would } \\
\text { you use for performance tracking? How frequently are } \\
\text { these measured? Who gets to see this KPI data? } \\
\text { c) If I were to walk through your factory could I tell how you } \\
\text { were doing against your KPI's? }\end{array}$ \\
\hline
\end{tabular}


Performance review

Performance dialogue

Consequence management

Target breadth

Target interconnection
Monitoring

6

Monitoring

c) Who gets to see the results of this review?

a) How are these meetings structured? Tell me about your most recent meeting.

b) During these meeting, how much useful data do you have?

c) How useful do you find problem solving meetings?

d) What type of feedback occurs in these meetings?

a) What happens if there is a part of the business (or a manager) who isn't achieving agreed upon results? Can you give me a recent example?

b) What kind of consequences would follow such an action?

c) Are there are any parts of the business (or managers) that seem to repeatedly fail to carry out agreed actions?

a) What types of targets are set for the company? What are the goals for your plant?

b) Tell me about the financial and non-financial goals?

c) What do Company Head Quarters (CHQ) or their appropriate manager emphasize to you?

a) What is the motivation behind your goals?

b) How are these goals cascaded down to the individual workers?

c) What are the goals of the top management team (do they even know what they are!)?

d) How are your targets linked to company performance and their goals? 
Target time horizon

Targets are stretching

Performance clarity and comparability

Managing human capital

Rewarding high performance
Targets

Targets
How are long term goals linked to short term goals?

c) Could you meet all your short-run goals but miss your longrun goals?

a) How tough are your targets? Do you feel pushed by them?

b) On average, how often would you say that you meet your targets?

c) Are there any targets which are obviously too easy (will always be met) or too hard (will never be met)?

d) Do you feel that on targets that all groups receive the same degree of difficulty? Do some groups get easy targets?

a) What are your targets (i.e. do they know them exactly)? Tell me about them in full.

b) Does everyone know their targets? Does anyone complain that the targets are too complex?

c) How do people know about their own performance compared to other people's performance?

a) Do senior managers discuss attracting and developing talented people?

b) Do senior managers get any rewards for bringing in and keeping talented people in the company?

c) Can you tell me about the talented people you have developed within your team? Did you get any rewards for this?

a) How does you appraisal system work? Tell me about the most recent round?

b) How does the bonus system work?

c) Are there any non-financial rewards for top-performers? 


\section{Removing poor performers}

Promoting high performers

Attracting human capital

Retaining human capital
Incentives

Incentives

Incentives a) If you had a worker who could not do his job what would you do? Could you give me a recent example?

b) How long would underperformance be tolerated?

c) Do you find any workers who lead a sort of charmed life? Do some individuals always just manage to avoid being fixed/fired?

a) Can you rise up the company rapidly if you are really good? Are there any examples you can think of?

b) What about poor performers - do they get promoted more slowly? Are there any examples you can think of?

c) How would you identify and develop (i.e. train) your star performers?

d) If two people both joined the company 5 years ago and one was much better than the other would he/she be promoted faster?

a) What makes it distinctive to work at your company as opposed to your competitors?

b) If you were trying to sell your firm to me how would you do this (get them to try to do this)?

c) What don't people like about working in your firm?

a) If you had a star performer who wanted to leave what would the company do?

b) Could you give me an example of a star performers being persuaded to stay after wanting to leave?

c) Could you give me an example of a star performer who left the company without anyone trying to keep them? 


\section{APPENDIX B: MATCHING CENSUS TO FIRM-LEVEL DATA}

To combine the firm-level survey data with the ONS census data we rely on a lookup table provided by the ONS mapping from CRN (Ralf: explain these acronyms and include acronym in a parenthesis) to IDBR. However, this lookup table is not complete for three reasons. First, for some records the ONS relied on name matching, which often does not lead to results if different names or spellings are used. Second, because the CRN and IDBR system are maintained independently the same businesses is sometimes represented differently in either register. The IDBR identifies business units according to functional units, which are relevant for the computing of government statistics. A CRN number is created whenever a company's management deems it necessary to register a new business name. Third, the lookup table is currently only provided for 2004 . Hence, there is no match for businesses created after this date. Table B1 provides descriptive statistics comparing a number of key statistics between matched and non-matched companies. A plant is matched with higher probability if it is older, larger, better managed and also owned by a larger firm.

We also subjected the data to a number of cleaning steps. Our key variables of interest in this study are factor expenditure and revenue shares. For a small number of firms factor revenue shares are either negative or larger than one (often several orders of magnitude larger). This is not consistent with any standard models of firm behaviour and likely a consequence of misreporting and measurement error; e.g. revenue being reported in 1000s and expenditure just in pound or vice versa. To avoid that our results are driven by any of this we firstly, we dropped establishments whose share of variable costs (materials plus labour cost) in gross output (VCOST/GO) was larger than one. We further dropped firms in the top and bottom percentile of the VCOST/GO distribution. Finally, we dropped establishments who had changes of more than 200 percent from year to year in VCOST/GO. Many of our results still go through even if we do not perform all of these steps. However, they ensure that things are more consistent; e.g. the dropping top and bottom percentiles is key for getting similar results when running either regressions of log factor shares or simply regression of factor shares.

Table B1 - Descriptive statistics of the matched sample

\begin{tabular}{lccc}
\hline \hline \multicolumn{1}{c}{ Variable } & Sample & Obs & Mean \\
\hline Employment at firm & unmatched & 263 & 444.45 \\
& matched & 338 & $528.5 * * *$ \\
Age & unmatched & 255 & 41.24 \\
\multirow{2}{*}{ Employment at plant } & matched & 337 & $45.53^{* * *}$ \\
& unmatched & 250 & 389.93 \\
Management Score & matched & 338 & $452.50^{* * *}$ \\
& unmatched & 263 & 2.93 \\
\hline \hline
\end{tabular}

Source: Authors' calculations based on census production (ARD) and CEP management survey data. Notes: The number of observations varies because of missing values for some variables for some firms.

*significant at $10 \% ; * *$ significant at $5 \% ; * * *$ significant at $1 \%$. 


\section{APPENDIX C: FURTHER RESULTS}

Table C1 - Management Practices and Energy Expenditure over Variable Costs

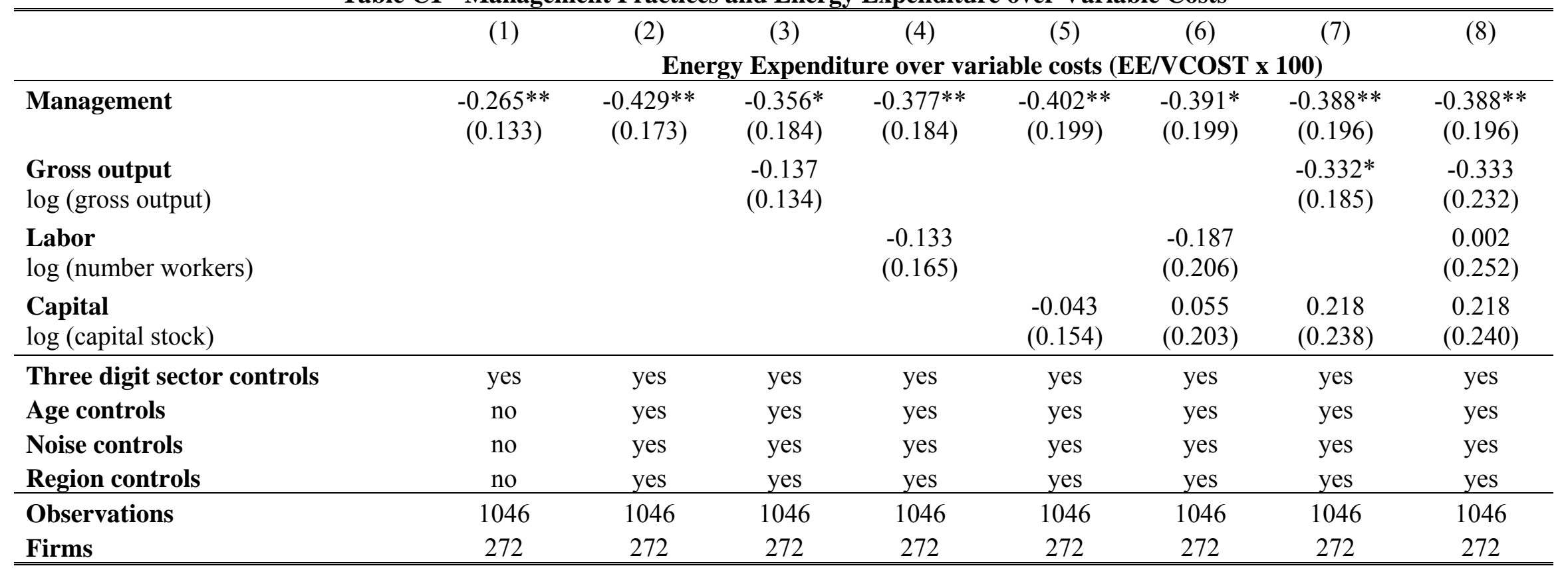

Source: Authors' calculations based on census production (ARD) and CEP management survey data.

Notes: The dependent variable in all regressions is energy expenditure over variable costs (labor costs and materials expenditure). All columns include a full set of year binary indicators. "Management" is the average scores across the eighteen questions on management practices from the CEP management survey; output and factor input variables (labor, capital, materials, energy) are from the census production data (ARD). Column 3 introduces gross output to control for size. A potential issue is that instead of output in volume units, we only observe revenue. We therefore also include the other production factors in subsequent columns, to correct for any possible scale effects. Noise controls are a set of variables capturing interview characteristics: duration and time of the interview, the gender of the interviewee, the reliability and competence of the interviewee as perceived by the interviewer and binary indicators for each interviewer. Standard errors clustered at the firm level (i.e. robust to heteroskedasticity and autocorrelation of unknown form) are reported in parenthesis below coefficients: *significant at 10\%; **ignificant at 5\%; ***significant at $1 \%$. 
Table C2 - Management Practices and Energy Expenditure
(1)
(2)
(3)
(4)

(5)

(6)

(7)

$(8)$

\begin{tabular}{|c|c|c|c|c|c|c|c|c|}
\hline Management & \multicolumn{8}{|c|}{ log Energy Expenditure (lnEE) } \\
\hline $\begin{array}{l}\text { Gross output } \\
\log \text { (gross output) }\end{array}$ & & & $\begin{array}{c}0.848^{* * *} \\
(0.054)\end{array}$ & & & & $\begin{array}{l}0.568 * * * \\
(0.102)\end{array}$ & $\begin{array}{c}0.372 * * * \\
(0.140)\end{array}$ \\
\hline $\begin{array}{l}\text { Labor } \\
\log \text { (number workers) }\end{array}$ & & & & $\begin{array}{c}0.998 * * * \\
(0.067)\end{array}$ & & $\begin{array}{c}0.544 * * * \\
(0.077)\end{array}$ & & $\begin{array}{c}0.334 * * * \\
(0.125)\end{array}$ \\
\hline $\begin{array}{l}\text { Capital } \\
\log \text { (capital stock) }\end{array}$ & & & & & $\begin{array}{c}0.758 * * * \\
(0.052)\end{array}$ & $\begin{array}{c}0.470^{* * *} \\
(0.070)\end{array}$ & $\begin{array}{c}0.311 * * * \\
(0.102)\end{array}$ & $\begin{array}{c}0.289^{* * * *} \\
(0.094)\end{array}$ \\
\hline Age controls & no & yes & yes & yes & yes & yes & yes & yes \\
\hline Noise controls & no & yes & yes & yes & yes & yes & yes & yes \\
\hline Region controls & no & yes & yes & yes & yes & yes & yes & yes \\
\hline Observations & 1046 & 1046 & 1046 & 1046 & 1046 & 1046 & 1046 & 1046 \\
\hline Firms & 272 & 272 & 272 & 272 & 272 & 272 & 272 & 272 \\
\hline
\end{tabular}

Source: Authors' calculations based on census production (ARD) and CEP management survey data.

Notes: The dependent variable in all regressions is the logarithm of energy expenditure. All columns include a full set of year binary indicators. "Management" is the average scores across the eighteen questions on management practices from the CEP management survey; output and factor input variables (labor, capital, materials, energy) are from the census production data (ARD). Column 3 introduces gross output to control for size. A potential issue is that instead of output in volume units, we only observe revenue. We therefore also include the other production factors in subsequent columns, to correct for any possible scale effects. Noise controls are a set of variables capturing interview characteristics: duration and time of the interview, the gender of the interviewee, the reliability and competence of the interviewee as perceived by the interviewer and binary indicators for each interviewer. Standard errors clustered at the firm level (i.e. robust to heteroskedasticity and autocorrelation of unknown form) are reported in parenthesis below coefficients: *significant at $10 \%$; **ignificant at $5 \%$; ***significant at $1 \%$ 
Table C3 - Management Practices and Log Energy Expenditure over Variable Costs

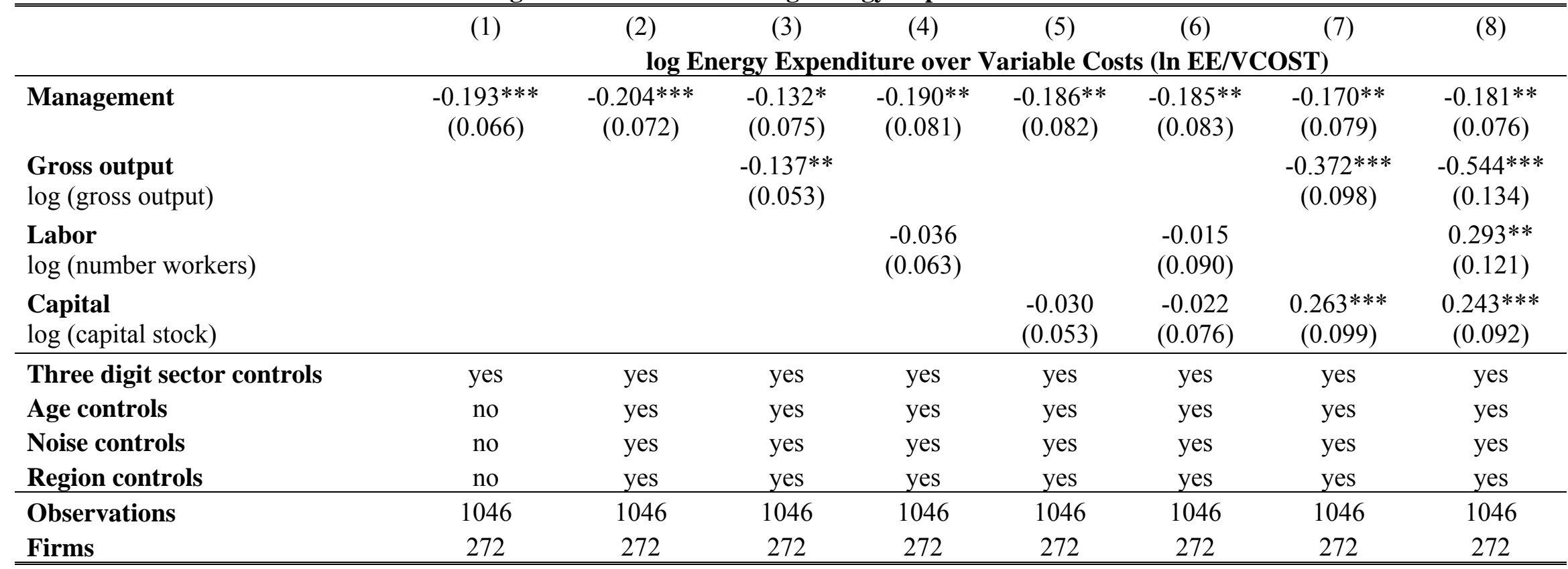

Source: Authors' calculations based on census production (ARD) and CEP management survey data.

Notes: The dependent variable in the above regressions is the logarithm of the energy expenditure over variable costs (labor costs and materials expenditure). All columns include a full set of year binary indicators. "Management" is the average scores across the eighteen questions on management practices from the CEP management survey; output and factor input variables (labor, capital, materials, energy) are from the census production data (ARD). Column 3 introduces gross output to control for size. A potential issue is that instead of output in volume units, we only observe revenue. We therefore also include the other production factors in subsequent columns, to correct for any possible scale effects. Noise controls are a set of variables capturing interview characteristics: duration and time of the interview, the gender of the interviewee, the reliability and competence of the interviewee as perceived by the interviewer and binary indicators for each interviewer. Standard errors clustered at the firm level (i.e. robust to heteroskedasticity and autocorrelation of unknown form) are reported in parenthesis below coefficients: *significant at $10 \%$; $* *$ significant at $5 \%$; *** significant at $1 \%$. 
APPENDIX D: CONVERSION FACTORS

Table D1 - Conversion Factors

\begin{tabular}{lccc}
\hline \hline & $\begin{array}{c}(1) \\
\text { Quantity } \\
\text { units in raw } \\
\text { data }\end{array}$ & $\begin{array}{c}(2) \\
\text { Conversion } \\
\text { factor to } \\
\mathbf{k W h *}\end{array}$ & $\begin{array}{c}(3) \\
\text { Conversion } \\
\text { factor to } \\
\text { CO2** }\end{array}$ \\
\hline Oil & Tonnes & 11972.22 & 0.3 \\
Gas Oil & Tonnes & 12666.67 & 0.3 \\
LPG & Tonnes & 13722.22 & 0.3 \\
Coal & Tonnes & 7500 & 0.31 \\
Hard Coke & Tonnes & 8277.77 & 0.44 \\
Gas & $\mathrm{kWh}$ & 1 & 0.21 \\
\hline \hline
\end{tabular}

Notes: *from DTI (2001); ** from Entech Utility Service Bureau

(http://www.entech.co.uk/entech/ener_conv.htm) 